\title{
Therapies from Fucoidan: New Developments
}

\author{
J. Helen Fitton *, Damien N. Stringer, Ah Young Park and Samuel S. Karpiniec \\ Marinova Pty Ltd., 249 Kennedy Drive, Cambridge, Tasmania 7170, Australia; \\ damien.stringer@marinova.com.au (D.N.S.); ahyoung.park@marinova.com.au (A.Y.P.); \\ sam.karpiniec@marinova.com.au (S.S.K.) \\ * Correspondence: helen.fitton@marinova.com.au; Tel.: +61-3-6248-5800
}

Received: 30 August 2019; Accepted: 6 October 2019; Published: 9 October 2019

\begin{abstract}
Since our last review in 2015, the study and use of fucoidan has extended in several research areas. Clinical use of fucoidan for the treatment of renal disease has become available and human safety studies have been undertaken on radiolabeled fucoidan for the purpose of imaging thrombi. Fucoidan has been incorporated into an increasing number of commercially available supplements and topical treatments. In addition, new measuring techniques are now available to assess the biologically relevant uptake of fucoidans and to assist in production. Microbiome modulation and anti-pathogenic effects are increasingly promising applications for fucoidans, due to the need for alternative approaches to antibiotic use in the food chain. This review outlines promising new developments in fucoidan research, including potential future therapeutic use.
\end{abstract}

Keywords: fucoidan; microbiome; analysis; norovirus

\section{Introduction}

Fucoidans are high molecular weight, fucose-based, sulphated polysaccharides from brown macroalgae [1]. Published research regarding fucoidans has continued to develop over the last three years, and a considerable array of products containing fucoidan extracts are now available. In the last review, we described the extraction and analysis for a range of macroalgal fucoidans, in addition to uptake and biological activity [1]. This review seeks to provide updates on analysis, regulatory status and current clinical usage of fucoidans. Other recent reviews provide a focus on promising areas of bioactivity [2], anticancer activity [3] and pharmaceutical dosage forms [4]. The commercial availability of fucoidans present in cosmetics, foods and nutritional supplements has increased. A fucoidan preparation called 'Haikun Shenxi capsules' was approved in China in 2003, and its clinical use as a therapeutic for chronic renal failure has been described [5]. There is now regulatory approval in the US and Europe for the use of fucoidans in supplements and cosmetics. There have been new developments in assay techniques for measuring fucoidans and establishing bioavailability. The first clinical trial on intravenous delivery of a radiolabelled fucoidan has now been reported [6]. This encouraging research focusses on the use of fucoidans to image thrombi and may become the first intravenous clinical application of fucoidan.

Despite earlier research into the potential of fucoidans to prevent post-surgical adhesions-an area of unmet clinical need-only one commercially available product for use in horses, called PERIDANTM, has eventuated [7]. A 2019 study confirmed the efficacy of both research grade Fucus vesiculosus and PERIDAN ${ }^{\mathrm{TM}}$ (Laminaria japonica) fucoidans in reducing abdominal adhesions in a rat model [8]. Interestingly, continuous infusion of either PERIDAN ${ }^{\mathrm{TM}}$ or Fucus vesiculosus fucoidan was sufficient to prevent adhesions, but as a single bolus, only fucoidan from Fucus vesiculosus was successful. At the time of writing, no human clinical trials are listed.

The effects of fucoidan on microbiome is an emerging area of focus. Global concern regarding the increase of drug-resistant superbugs and the lack of new antibiotics for treating human and animal 
diseases has led to a call for new approaches. In agriculture, there is an urgent need to develop strategies to replace antibiotics for food-producing animals, especially poultry and livestock. In human health, there is increasing awareness of a connection between the microbiome and disease conditions. Fucoidans have bacteria-inhibiting qualities against the ulcer-causing Helicobacter pylori [9-11], and modulate the growth and biofilm-forming properties of other types of bacteria [12]. Additional antiviral activity and the anti-inflammatory nature of fucoidans [1] make them suitable for a wide range of digestive tract applications. In particular, fucoidans can attenuate inflammation generated by lipopolysaccharides produced by Gram-negative bacteria [13]. New research demonstrates activity against norovirus, for which there are no current treatments [14]. Perhaps much of the biological activity ascribed to fucoidans may be due their effects on modulating microbiome and inflammation from the oral cavity and throughout the length of the gut.

The use of fucoidans as potential agents in oncology has been recently reviewed by others and is briefly expanded upon here [3,15]. The mechanism by which fucoidans could induce either a direct or indirect anticancer effect is better understood. The modulation of immune activity by fucoidans shows promise, not only as an anti-inflammatory agent, but also as a potential vaccine adjuvant. This immune-modulatory effect may also represent an additional anticancer mechanism for fucoidans. Observations in elderly Japanese subjects showed that oral administration of a fucoidan extract enhanced their response to influenza vaccines [16]. The mechanism for this useful activity may be associated with the ability of fucoidans to bind to Toll-like receptors [17]. Another emerging application in the literature is the use of fucoidans in ocular diseases [18], particularly age-related macular degeneration due to their ability to interfere with the activity of vascular endothelial growth factor (VEGF) [19].

\section{Bioavailability and Measurement of Fucoidans}

Measuring fucoidans during extraction processes, and in biological tissues and fluids, remains technically challenging. Standard laboratory methods for analysis have been outlined previously [1]. Recent developments in measurements in biological fluids include an electrochemical interface method [20], and a highly sensitive dye-based method, now commercially available from the analytical company, Redprobes [21]. A summary of recent developments is outlined in Table 1.

Table 1. Recent fucoidan measurement techniques.

\begin{tabular}{cccc}
\hline Fucoidan Source & Method & Outcome & Reference \\
\hline $\begin{array}{c}\text { Fucus vesiculosus Undaria } \\
\text { pinnatifida }\end{array}$ & $\begin{array}{c}\text { Electrochemical interface } \\
\text { measuring technique }\end{array}$ & $\begin{array}{c}\text { Detection at low } \mu \mathrm{mL}^{-1} \\
\text { concentration. }\end{array}$ & [20] \\
\hline $\begin{array}{c}\text { Fructan fucoidan blends } \\
\text { Sea cucumber }\end{array}$ & FT-IRs & Food analysis and confirmation & {$[22]$} \\
\hline $\begin{array}{c}\text { Stichopus japonicus } \\
\text { Macrocystis pyrifera }\end{array}$ & for quantitation & $\begin{array}{c}\text { Able to differentiate fucosylated } \\
\text { chondroitin sulfate and fucoidan }\end{array}$ & {$[23]$} \\
\hline
\end{tabular}

Interestingly, some fucoidan preparations sold commercially for use in food and supplements may not contain fucoidan as stated. Some preparations appear to be alternative polysaccharides, perhaps laminarin, whilst others may be substituted with glucose or cellulose [24].

The oral bioavailability of fucoidan preparations is generally low, although recent studies have elegantly demonstrated the uptake and tissue distribution of Fucus vesiculosus fucoidan in a rat model [25]. A Japanese study has further confirmed the bioavailability of fucoidan and its excretion in urine, after ingestion of whole seaweed [26]. This follows their earlier work demonstrating the uptake of orally delivered fucoidan in serum and urine [27]. Uptake studies are outlined in Table 2. The recently described observations of clinical efficacy of orally delivered fucoidan for chronic renal failure indicate 
probable systemic uptake [5] in humans. Systemic uptake after oral delivery indicates potential for additional clinical applications in the future, perhaps including the control of thrombosis [28].

Table 2. Uptake and distribution of fucoidan.

\begin{tabular}{cccc}
\hline Fucoidan Source & Study Type & Outcome & Reference \\
\hline Fucus vesiculosus & Rat tissue distribution & Inverse detection method & [25] \\
\hline Fucus vesiculosus & Mouse-fluoro labelled fucoidan & $\begin{array}{c}\text { Detected by fluorescence } \\
\text { spectrometry and HPLC }\end{array}$ & {$[29]$} \\
\hline Cladosiphon okamuranus & Clinical study-urine and & $\begin{array}{c}\text { Detected uptake in urine } \\
\text { serum }\end{array}$ & {$[26]$} \\
\hline
\end{tabular}

\section{Regulatory Framework for the Use of Fucoidans}

\section{Food and Supplements}

In recent years, fucoidan extracts have attained regulatory approvals in a number of global jurisdictions for use in foods and dietary supplements. In particular, fucoidan extracts from Undaria pinnatifida and Fucus vesiculosus were filed as 'Generally Recognised as Safe' (GRAS) with the US FDA by the Australian manufacturer, Marinova. The FDA had no further questions in relation to the two GRAS determinations, which permit daily consumption of high-concentration fucoidan extracts from Undaria pinnatifida or Fucus vesiculosus at rates of up to $250 \mathrm{mg} /$ day.

In the European Union, the same fucoidan extracts from Undaria pinnatifida and Fucus vesiculosus were assessed by the European Commission and found to be substantially equivalent to the parental seaweeds from which they are extracted, and hence were approved as novel foods under the Commission Implementing Regulation (EU) 2017/2470 of 20 December 2017, for consumption up to $250 \mathrm{mg}$ /day.

In Canada and Australia, the respective agencies have approved a number of listed medicines containing fucoidan extracts. In Australia, fucoidans have been approved in a species-specific context for both Undaria pinnatifida and Fucus vesiculosus. They are recognised as listable components of their parental herbal (seaweed) source.

\section{Clinical Use of Fucoidan Extracts}

The first clinical trial on intravenous delivery of a radiolabelled fucoidan has now been reported [6]. The ability of fucoidans to bind to p-selectin groups on platelets assists in the imaging of blood flow-limiting thrombi. This application may become the first non-oral clinical application of fucoidan.

Reports of orally delivered clinical use of fucoidans have increased in the last few years. A recent paper outlines the use of fucoidan from Saccharina japonica to address kidney disease in China [5]. This traditional Chinese medicine formulation shows promise for use in other parts of the world and is supported by studies in the literature detailing the use of fucoidan to treat kidney disease in a variety of animal models. Mesenchymal stem cells (MSCs) are a class of cells that show promise in regenerating diseased organs [30]. Currently, the damage caused to MSCs by uremic toxins makes kidney MSC transplantation unfeasible. However, fucoidan from Fucus vesiculosus reversed senescence caused by the uremic toxin p-cresol, indicating a potential support for both resident and transplanted MSCs [31].

Following on from an animal study showing inhibition of inflammation in ethanol-induced gastritis [32], a clinical study in young Chinese men showed a substantial—and no doubt welcomedecrease in gastritis (cause undisclosed) after ingestion of a blend of fucoidan and wheat peptides [33].

Additional studies have demonstrated fucoidans utility in reducing inflammation in cancer patients [34]. No interactions or adverse effects were observed with the commonly used hormone therapies tamoxifen and letrozole in breast cancer patients. Reductions in joint pain were also noted following co-administration of fucoidan from Undaria pinnatifida [35]. 
Fucoidan administration improved taste sensitivity in diabetics [36], whilst a study on obese, but non-diabetic, subjects using a fucoidan-polyphenol complex from Fucus vesiculosus showed no effects on glucose or insulin resistance [37].

Lastly, a clinical topical study using a cream containing $4 \%$ fucoidan was found to be effective for treating oral herpes [38]. This topical application is supported by a substantial body of research indicating excellent inhibitory activity against herpes viruses [39]. These recent clinical studies are further summarised in Table 3.

Table 3. Clinical studies involving fucoidan.

\begin{tabular}{|c|c|c|c|c|}
\hline Fucoidan Source & Aim of Study & Type of Study & Outcome & Reference \\
\hline Saccharina japonica & $\begin{array}{l}\text { To review use of fucoidan to treat } \\
\text { renal diseases and discuss clinical } \\
\text { outcomes for Haikun Shenxi capsule } \\
\text { in chronic renal failure patients }\end{array}$ & Clinical study and review & $\begin{array}{l}\text { Fucoidan inhibits renal fibrosis and } \\
\text { glomerular sclerosis by reducing the } \\
\text { accumulation of extracellular matrix. }\end{array}$ & {$[5]$} \\
\hline Unspecified & $\begin{array}{l}\text { To establish safety of a radiolabeled } \\
\text { fucoidan }\end{array}$ & $\begin{array}{l}\text { Clinical Healthy subjects } \\
\text { Intravenous }\end{array}$ & Fucoidan is safe. Distribution established. & {$[6]$} \\
\hline Cladosiphon sp. & $\begin{array}{l}\text { To examine the efficacy of fucoidans } \\
\text { especially focusing on inflammation } \\
\text { in relation to (QOL)quality of life } \\
\text { scores for advanced cancer patients }\end{array}$ & $\begin{array}{l}\text { Clinical } \\
\text { Cancer patients }\end{array}$ & $\begin{array}{l}\text { Pro-inflammatory cytokines significantly } \\
\text { reduced after two weeks of fucoidan } \\
\text { ingestion and QOL scores stayed. }\end{array}$ & [34] \\
\hline Cladosiphon sp. & Absorption study & Clinical Healthy Subjects & $\begin{array}{l}\text { Residents in Okinawa prefecture had } \\
\text { significantly higher fucoidan excretion. }\end{array}$ & [40] \\
\hline Unspecified & $\begin{array}{l}\text { To evaluate the protective effect of } \\
\text { the combination of wheat peptides } \\
\text { and fucoidan (WPF) on adults } \\
\text { diagnosed with chronic superficial } \\
\text { gastritis }\end{array}$ & $\begin{array}{l}\text { Clinical Chronic gastritis } \\
\text { patients }\end{array}$ & $\begin{array}{l}\text { WPF reduced gastric mucosal damage and } \\
\text { improved symptoms and altered gut } \\
\text { microbial profile in beneficial way. }\end{array}$ & [33] \\
\hline Fucus vesiculosus & $\begin{array}{l}\text { To determine if fucoidan/polyphenol } \\
\text { extract reduces insulin resistance }\end{array}$ & $\begin{array}{l}\text { Clinical } \\
\text { Overweight non-diabetic } \\
\text { subjects }\end{array}$ & $\begin{array}{l}\text { Safety affirmed. No effects on insulin, } \\
\text { glucose. }\end{array}$ & [37] \\
\hline Undaria pinnatifida & $\begin{array}{l}\text { To investigate the effect of } \\
\text { co-administration of fucoidan on } \\
\text { letrozole and tamoxifen. }\end{array}$ & $\begin{array}{l}\text { Clinical interaction study } \\
\text { Breast cancer patients }\end{array}$ & $\begin{array}{l}\text { Fucoidan is safe to be taken with letrozole } \\
\text { and tamoxifen. }\end{array}$ & [35] \\
\hline Nemacystus decipiens & $\begin{array}{l}\text { To determine efficacy of } 4 \% \text { fucoidan } \\
\text { cream for recurrent oral herpes } \\
\text { labialis }\end{array}$ & $\begin{array}{l}\text { Clinical } \\
\text { Topical study Patients } \\
\text { with cold sores }\end{array}$ & $\begin{array}{l}\text { Recurrent oral herpes labialis was } \\
\text { markedly improved by the cream in terms } \\
\text { of both healing and time to loss of } \\
\text { discomfort. }\end{array}$ & [38] \\
\hline
\end{tabular}

\section{Biomaterials and Drug Delivery}

Functionalities offered by fucoidans have been exploited in numerous experimental biomaterials. The P-selectin binding activity of a fucoidan extract has led to the development of a radiolabeled thrombus-marking preparation to enable imaging. A clinical trial was recently completed on the tolerance, biodistribution and dosimetry of fucoidan radiolabeled by Technetium-99m $[6,41]$.

The anti-inflammatory properties of fucoidans have also been utilised in combination peptide gels [42]. The addition of a fucoidan extract aided the formation of fibrillary peptide gels which were then assessed in vitro and in vivo. These gels were used to provide a scaffold for the regeneration of brain tissue and the prevention of scar formation [43]. In similar preparations, the fucoidan extract caused apoptosis in an epithelial cancer cell line [44], indicating the potential of the gel to restrict cancer recurrence at the surgical excision site.

There is an especially rich variety of new literature in the area of drug delivery, as reviewed recently [4]. For example, fucoidan-containing films have been investigated for their potential in drug delivery systems. In one study, polyelectrolyte multilayers (PAMs) were formed using chitosan and different molecular weight fractions of Fucus vesiculosus fucoidan [45]. It was found that the different fucoidan fractions greatly altered the structure of the PEMs, affecting hydration, elasticity and the capacity and type of small molecules to migrate through the material. This could allow for a variety of specialised wound dressings to be developed with different affinities for proteins, or to allow for the migration of functional molecules to the wound site to aid the healing process. 
Another novel drug delivery system was developed based on the self-assembly of two polyelectrolytes, poly-allylamine hydrochloride $(\mathrm{PAH})$ and a fucoidan extract. This system was developed to deliver the anticancer drug methotrexate, [46]. Such drug delivery systems may eventually allow lower amounts of drug to be delivered over a sustained period of time in order to maximise anticancer effects. Enhanced immune regulation activity against breast cancer was developed using fucoidan nanoparticles containing doxorubicin [47], while another type of fucoidan-chitosan coated gold nanorod was developed for photo-initiated anticancer therapy using far infrared light [48]. These generated positive results after laser treatment of breast cancer tumours in mice. Manganese fucoidan nanoparticles reversed hypoxia-induced radiotherapy resistance by decreasing clonogenic survival and increasing DNA damage and apoptotic cell death [49]

Immobilised fucoidans on a variety of surfaces have also assisted in bone regeneration models [50] and in the prevention of coagulation [51]. A materials science application for fucoidans, in the form of immobilised fucoidan on steel surfaces, has potential to inhibit the surface adhesion and transfer of infectious agents and inhibit biofouling [52]. This novel approach may have utility in coating surgical instruments and implantable devices. Studies are summarized in Table 4.

Table 4. Biomaterials and drug delivery.

\begin{tabular}{|c|c|c|c|c|}
\hline Fucoidan Source & Aim of Study & Type of Study & Effect & Reference \\
\hline Unspecified & $\begin{array}{l}\text { Functionalised microbubble P-selectin } \\
\text { markers for thrombus }\end{array}$ & In vivo & $\begin{array}{l}\text { Fucoidan microbubbles were able to target } \\
\text { thrombus specifically. }\end{array}$ & [53] \\
\hline Undaria pinnatifida & Peptide gels for scaffolds & In vitro & Fucoidan generates fibrillary peptide gels & [42] \\
\hline Undaria pinnatifida & Peptide gels in brain injury & In vivo & Reducing astrocytic scarring & [43] \\
\hline Undaria pinnatifida & $\begin{array}{l}\text { Peptide gel control of muscle cell } \\
\text { morphology }\end{array}$ & In vitro & $\begin{array}{l}\text { Fucoidan peptide gels reduce formation of } \\
\text { mutinucleated syncytia in myoblasts }\end{array}$ & [54] \\
\hline Laminaria japonica & $\begin{array}{l}\text { Eggshell protein chitosan fucoidan for } \\
\text { intestinal inflammation }\end{array}$ & In vivo & $\begin{array}{l}\text { Reduced lipopolysaccharide } \\
\text { (LPS)-induced intestinal epithelial } \\
\text { inflammation }\end{array}$ & [55] \\
\hline Fucus vesiculosus & Bone regenerations fucoidan peptide & In vitro & $\begin{array}{l}\text { Developed a new mechanically and } \\
\text { thermally stable bioorganic scaffold for } \\
\text { bone tissue engineering }\end{array}$ & {$[50]$} \\
\hline Fucus vesiculosus & $\begin{array}{l}\text { Electrospun mats with fucoidan for } \\
\text { osteoblasts }\end{array}$ & In vitro & $\begin{array}{l}\text { Enhanced stability of the surface of blend } \\
\text { nanofibers with very good cell viability }\end{array}$ & [56] \\
\hline Fucus vesiculosus & Fish oil encapsulation & $\mathrm{n} / \mathrm{a}$ & Significantly improved oxidative stability & [57] \\
\hline Fucus vesiculosus & Targeted nanoparticles cancer therapy & In vivo & $\begin{array}{l}\text { Directly induced T-cell activation and } \\
\text { blocked the immunosuppressive PD-L1 } \\
\text { pathways via intravenous administration. }\end{array}$ & [58] \\
\hline Laminaria japonica & $\begin{array}{l}\text { Hydrogels with fucoidan for platelet } \\
\text { rich plasma delivery into connective } \\
\text { tissues }\end{array}$ & In vivo & $\begin{array}{l}\text { Hydrogel showed high strength, stability, } \\
\text { strong adhesive ability and promoted } \\
\text { cartilage regeneration in a rabbit. }\end{array}$ & [59] \\
\hline Fucus vesiculosus & $\begin{array}{l}\text { Anticoagulant plasma fucoidan on } \\
\text { plastic surface }\end{array}$ & In vitro & $\begin{array}{l}\text { Fully anticoagulant and suitable for blood } \\
\text { contacting PET devices }\end{array}$ & {$[60]$} \\
\hline Fucus vesiculosus & Antifouling coating of solid surfaces & In vitro & $\begin{array}{l}\text { Catechol-conjugated fucoidan coating } \\
\text { showed excellent resistance to platelets, } \\
\text { bacteria and marine diatom adhesions. }\end{array}$ & [52] \\
\hline
\end{tabular}

\section{Microbiome and Fucoidan}

Oral, digestive and skin microbiomes can all be modulated by the presence of fucoidans. As research into the microbiome, virome and phageome develops, the interactions between the microbiome and disease states continue to unfold. The efficacy of drugs and checkpoint inhibitor therapy [61], responses [62], cancer [63], obesity, inflammatory disorders [64] and mental health [65] have all been associated with microbiome.

Fucoidans have been noted to create favourable changes in the microbiome [66] and additionally, to independently modulate checkpoint PD-L1 in cancer cells [67]. The microbiome and intestinal integrity in a breast cancer-bearing rat model was favourably affected by fucoidan intake [68]. These alterations could be considered as an additional potential mechanism by which fucoidans can act as a preventative to breast cancer. 
Oral bacteria were affected particularly by fucoidan from Fucus vesiculosus, at inhibitory concentrations below $1 \mathrm{mg} / \mathrm{mL}$. The inhibition of biofilm formation and planktonic cell growth was also observed, showing promise for the inclusion of fucoidans in dental products [12,69].

Gastric damage was markedly inhibited by a fucoidan-containing preparation in a double blind clinical study [70]. An interesting new development showed that fucoidan has the ability to prevent gastric mucosa adhesion of the highly infectious norovirus, for which there are no effective preventatives or treatments [14]. Building on earlier research demonstrating the inhibition of influenza viruses by fucoidan, a synthetic fucoidan was shown to be highly effective in binding viral hemagglutinin [71].

There is great potential for fucoidans to both modulate microbiome and prevent the binding of infectious pathogens. Studies are summarized in Table 5.

Table 5. Microbiome and pathogen effects.

\begin{tabular}{|c|c|c|c|c|}
\hline Fucoidan Source & Aim of Study & Type of Study & Effect & Reference \\
\hline Laminaria japonica & $\begin{array}{l}\text { Wheat peptides and } \\
\text { fucoidan }\end{array}$ & In vivo (Rat) & $\begin{array}{l}\text { Amelioration of gastric inflammation } \\
\text { caused by ethanol }\end{array}$ & [32] \\
\hline Laminaria japonica & $\begin{array}{l}\text { Microbiome in mice } \\
\text { with DMBA-induced } \\
\text { breast cancer }\end{array}$ & In vivo (Mice) & $\begin{array}{l}\text { Increased bacteroidetes/firmicutes phylum } \\
\text { ratio, increased tight junction proteins and } \\
\text { lowered endotoxin }\end{array}$ & [68] \\
\hline $\begin{array}{l}\text { Fucus vesiculosus } \\
\text { Cladosiphon sp. }\end{array}$ & Oral healthcare biofilms & In vitro & $\begin{array}{l}\text { Candida albicans, Streptococcus mutans, and } \\
\text { Porphyromonas gingivalis; significantly } \\
\text { inhibited the adhesion of S. mutans to } \\
\text { bovine teeth and porcelain; were } \\
\text { suggested to bind to and neutralise } \\
\text { endotoxin (lipopolysaccharide) in a LAL } \\
\text { assay; and showed COX-1 and/or COX-2 } \\
\text { inhibitory activity }\end{array}$ & [12] \\
\hline Synthetic fucoidan activity & $\begin{array}{l}\text { Influenza virus } \\
\text { infection }\end{array}$ & $\begin{array}{l}\text { In vitro viral } \\
\text { MDCK plaque } \\
\text { assay }\end{array}$ & $\begin{array}{l}\text { Bound to influenza virus haemagglutinins } \\
\text { (HAs) and inhibited haemagglutination } \\
\text { activity. }\end{array}$ & [71] \\
\hline Kjellmaniella crassifolia & $\begin{array}{l}\text { Influenza virus } \\
\text { infection }\end{array}$ & In vitro & $\begin{array}{l}\text { Bound to and inhibited viral } \\
\text { neuraminidase and interfered with the } \\
\text { activation of EGFR, PKC } \alpha, N F-\kappa B \text {, and } \\
\text { Akt; intranasal administration improved } \\
\text { survival and decreased viral titres. }\end{array}$ & [72] \\
\hline
\end{tabular}

\section{Oncology}

As described previously, fucoidans appear to act both directly on cancer cells and indirectly, by increasing immune clearance of cancer cells and preventing metastasis. For example, tumour metastasis and cachexia were attenuated via the inhibition of vascular endothelial growth factor (VEGF) and matrix metalloproteases in a Lewis lung cancer tumour model mice given oral fucoidan [73].

Fucoidans act independently as checkpoint modulators and may serve as alternative complementary agents for the treatment of cancers with high PD-L1 expression [67]. Apoptosis or cell cycle arrest appears as a common feature of fucoidan bioactivity directly on cancer cells. Uterine cancer cell lines were inhibited by fucoidans derived from Undaria pinnatifida, whilst normal cells were unaffected [74]. Lower molecular weight fractions of Undaria fucoidan were highly effective inhibitors of human prostate cancer cells, when delivered orally in a xenografted mouse model [75]. Head and neck cancers, which may be caused by human papilloma viruses (HPV), are particularly difficult to treat. Fucoidan from Fucus vesiculosus inhibited head and neck squamous cell lines, causing cell cycle arrest [76]. It also enhanced the response to the anticancer drug cisplatin in HPV-affected lines. Preclinical evaluations of fucoidans from Fucus 
vesiculosus and Undaria pinnatifida in a mouse model showed activity as sole agents and additive activity with anticancer agents in some breast cancer and ovarian cancer tumours [77]. It should be noted that fucoidans do not always act as inhibitors of cancer cell lines, and were ineffective against uveal melanoma cell lines [78], instead providing protective and angiogenic effects.

The mechanisms of these anticancer activities are multifaceted. They include induction [79], or even inhibition [76], of reactive oxygen species, destabilization of mitochondria, and the cleavage of caspases and PARP. Using a systematic screen of the entire set of 4733 haploid Saccharomyces cerevisiae gene deletion strains, an analysis of cell pathways revealed that multiple cellular pathways were affected by exposure to fucoidan extracts, and that cDNA damage and cell cycle arrest occurred in colon cancer cell lines. Normal fibroblasts were unaffected under the same conditions [80]. There were global effects of the fucoidan studied on a wide range of eukaryotic cellular processes, including RNA metabolism, protein synthesis, sorting, targeting and transport, carbohydrate metabolism, mitochondrial maintenance, cell cycle regulation and DNA damage repair-related pathways. Thus, the mechanisms by which fucoidans may act on cancer cells is becoming clearer. The lack of effect on normal fibroblasts means that fucoidan extracts have potential utility as anticancer agents.

In a Russian study, fucoidan from Fucus evanescens was found to increase cancer susceptibility towards radiation [81]. The growing amount of evidence described above suggests that fucoidans place stresses on multiple cellular pathways, thereby increasing cancer cell susceptibility to radiation or other agents. Conversely, fucoidans may confer radiation protection effects that help to prevent lung damage and subsequent fibrosis of healthy tissues [82].

The immunosuppression experienced after chemotherapy can lead to infectious diseases and reduced quality of life. Previous research has shown some increase in circulating stem cells after ingestion of a fucoidan extract [83]. In a recent Russian study, semisynthetic fucoidan fractions were assessed in a cyclophosphamide immune-suppressed mouse model. A subcutaneously delivered fucoidan-derived octasaccharide was more effective in neutrophil regeneration than the gold standard peptide treatment, rG-CSF [84]. Recent research is summarized in Table 6.

Table 6. In vitro and in vivo cancer studies.

\begin{tabular}{|c|c|c|c|c|}
\hline Source of Fucoidan & Aim of Study & Type of Study & Outcome & Reference \\
\hline $\begin{array}{l}\text { Undaria pinnatifida } \\
\text { Fucus vesiculosus }\end{array}$ & Orthotopic cancers in mice & In vivo Mouse & $\begin{array}{l}\text { Safety of fucoidan usage during breast } \\
\text { cancer treatment and potential to improve } \\
\text { tamoxifen activity. }\end{array}$ & {$[77,85]$} \\
\hline Semisynthetic fucoidan fraction & $\begin{array}{l}\text { Cyclophosphamide-treated } \\
\text { mice, haemopoiesis }\end{array}$ & In vivo mouse & $\begin{array}{l}\text { Synthetic octasaccharide is identified as an } \\
\text { effective stimulator of haematopoiesis. }\end{array}$ & {$[84]$} \\
\hline Undaria pinnatifida & $\begin{array}{l}\text { Cell cycle arrest in HCT116 } \\
\text { and MOA yeast gene deletion } \\
\text { study }\end{array}$ & In vitro & $\begin{array}{l}\text { Global effects of fucoidan on a wide range } \\
\text { of eukaryotic cellular processes and } \\
\text { inhibitory effect on colon cancer cells. }\end{array}$ & {$[80]$} \\
\hline Undaria pinnatifida & $\begin{array}{l}\text { Uterine carcinoma and } \\
\text { sarcoma cell lines }\end{array}$ & In vitro & $\begin{array}{l}\text { Anticancer agent activity against } \\
\text { endometrial stromal sarcoma and } \\
\text { carcinosarcoma. }\end{array}$ & [74] \\
\hline Fucus evanescens & $\begin{array}{l}\text { Radio sensitisation human } \\
\text { melanoma, breast } \\
\text { adenocarcinoma, and } \\
\text { colorectal carcinoma cell lines }\end{array}$ & In vitro & $\begin{array}{l}\text { Increased the inhibitory effect of X-ray } \\
\text { radiation on proliferation and colony } \\
\text { formation-activating caspases, suppressed } \\
\text { anti-apoptotic protein and enhanced } \\
\text { fragmentation of DNA. }\end{array}$ & [81] \\
\hline Fucus vesiculosus & $\begin{array}{l}\text { Radiation-induced lung } \\
\text { fibrosis }\end{array}$ & $\begin{array}{l}\text { In vivo } \\
\text { mouse }\end{array}$ & $\begin{array}{l}\text { Fucoidan changed the expression patterns } \\
\text { of inflammatory cytokines and attenuated } \\
\text { radiation-induced lung fibrosis }\end{array}$ & [82] \\
\hline
\end{tabular}

\section{Imaging and Control of Coagulation}

French researchers have developed an extensive body of work regarding the use of radiolabelled fucoidan as an imaging agent to locate thrombi and image early-stage inflammatory processes in autoimmune endocarditis [86,87]. A clinical trial on the safety of the reagent was completed in 2019 [6], clearing the way for commercialization and clinical use of this imaging tool.

This work has expanded to assist in the targeting of thrombi to deliver a clinically used thrombolytic agent, recombinant tissue plasminogen activator (rtPA). A fucoidan extract is incorporated into 
nanoparticles which are then loaded with the rtPA. This allows the specific targeting of thrombi at lower overall doses, and may avoid some of the haemorrhagic complications of using rtPA [88]. Interestingly, fucoidans themselves are good inhibitors of the tPA-PASI1 complex, and act as thrombolytics in their own right. Combined Korean- and Russian-based research has demonstrated the utility of these fractions, building on earlier work that demonstrated anti-thrombotic activity without anticoagulant activity in a fraction from Undaria pinnatifida. [89]. The potential to use orally bioavailable thrombolytic approaches are attractive [28].

Dextran-coated superparamagnetic iron oxide nanoparticles or 'SPIONs' are in use as MRI contrast agents. The wider clinical potential of SPIONs is limited by their rapid removal from circulation via the reticuloendothelial system (RES). Fucoidan ingestion appears to increase the retention time of SPIONs by preventing their uptake into the reticuloendothelial system [90-92]. This useful activity expands on the applications for imaging of thrombi.

Gradually depolymerised fractions of Fucus vesiculosus fucoidans (without removing sulphates) were examined for bioactivity [91,92]. Researchers concluded that the fractions gradually lost their anti-oxidative and anti-proliferative activities due to the removal of terpenoids and polyphenolics. It is likely that the terpenoid and polyphenolic components were co-extracted with the initial fucoidan and subsequently removed, rather than being incorporated within the structure of the fucoidan polymer itself. Interestingly, lower molecular weight fractions maintained an anti-inflammatory activity, whilst having a low anticoagulant activity. Studies are summarized in Table 7.

Table 7. Imaging and coagulation studies.

\begin{tabular}{|c|c|c|c|c|}
\hline Fucoidan Source & Aim of Study & Type of Study & Outcome & Reference \\
\hline $\begin{array}{l}\text { Radiolabelled fucoidan source } \\
\text { unspecified }\end{array}$ & Safety & Human clinical & $\begin{array}{l}\text { Safe to use. Maximum activity in liver. } \\
\text { Activity reduced to }<5 \% \text { after } 24 \mathrm{~h} \text {. }\end{array}$ & [6] \\
\hline Laminaria japonica & Anti-thrombotic & $\begin{array}{l}\text { In vivo mouse } \\
\text { model. } \\
\text { Oral delivery }\end{array}$ & Lower MW fucoidan was most effective & [28] \\
\hline $\begin{array}{l}\text { Fucus vesiculosus and } 18 \\
\text { gradually depolymerised } \\
\text { fractions }\end{array}$ & $\begin{array}{l}\text { Degraded fucoidan } \\
\text { fractions }\end{array}$ & In vitro & $\begin{array}{l}\text { Anti-inflammatory activity, however only } \\
\text { negligible anticoagulant activity and } \\
\text { FXII-activating potency }\end{array}$ & [91] \\
\hline
\end{tabular}

\section{Neuroprotection}

One of the key issues with natural or drug agents for neuroprotection is the blood-brain barrier. Whilst systemic effects can undoubtedly translate to brain effects, any direct actions will ultimately need a delivery system into the central nervous system.

Having said that, new avenues of research into fucoidans as neuroprotective agents are promising. In a model of transient ischemia, fucoidans delivered by intraperitoneal (ip) means were found to effectively protect neurons from ischemic events through attenuation of activated glial cells and reduction of oxidative stress via increase of super oxide dismutase production [93]. In Alzheimer's related research, a fucoidan extract inhibited the formation of amyloid fibrils in vitro, and their toxic effect on neuronal cells [94].

Various models of Parkinson's disease treated with fucoidans have shown encouraging data $[95,96]$. While the mechanism behind these results is unclear, the recent findings on microbiome connections with Parkinson's disease and many other neurological conditions point to a potential effect on gut microbiota [97]. Recent research is summarized in Table 8. 
Table 8. Neuroprotection in vitro and in vivo.

\begin{tabular}{llll}
\hline \multicolumn{1}{c}{ Fucoidan Source } & Type of Model & Outcome & Reference \\
\hline $\begin{array}{l}\text { Undaria pinnatifida, } \\
\text { Fucus vesiculosus }\end{array}$ & $\begin{array}{l}\text { Neuroprotection in vitro, } \\
\text { Alzheimer's models }\end{array}$ & $\begin{array}{l}\text { Fucoidan inhibits formation of amyloid } \\
\text { fibrils }\end{array}$ & [94] \\
\hline Fucus vesiculosus & $\begin{array}{l}\text { Neuroprotection in vivo, } \\
\text { intraperitoneal mouse } \\
\text { model }\end{array}$ & $\begin{array}{l}\text { IP fucoidan protects against transient } \\
\text { ischemia }\end{array}$ & {$[93]$} \\
\hline Laminaria japonica & $\begin{array}{l}\text { Rotenone Parkinson's } \\
\text { model in mouse }\end{array}$ & $\begin{array}{l}\text { Protection of dopamine system via } \\
\text { preserving mitochondrial function } \\
\text { involving the PGC-1 } \alpha / \text { NRF2 pathway }\end{array}$ & {$[98]$} \\
\hline Unspecified & $\begin{array}{l}\text { Parkinson's type } \\
\text { research in vitro }\end{array}$ & $\begin{array}{l}\text { Protective effects for dopaminergic } \\
\text { neural cells }\end{array}$ & {$[95]$} \\
\hline
\end{tabular}

\section{Conclusions}

Fucoidans continue to be developed as bioactive oral supplements and will likely increase their market presence in the future. Gut health, oral health and anti-inflammatory applications are already partly commercialised for use in humans, livestock and pets, with the recent suite of regulatory approvals for fucoidan extracts in the US and EU likely to spur further growth in these sectors.

Promising research, even when patented, often fails to be commercialised due to lack of regulatory approval and a clear need in the market. Regulatory approval of a fucoidan preparation for chronic renal failure has provided clinically useful outcomes in China. Fucoidans have enormous potential as part of drug delivery systems and devices, and they show particular near-market potential in imaging and in treatments for thrombosis. Safety studies on radiolabelled fucoidan have been carried out with a view to regulatory approval for clinical imaging applications. Subject to regulatory approvals, fucoidans could be used in the near future.

Orally bioavailable adjunct therapies for neurological disease, bacterial and viral infections, and oncology also appear to be commercial possibilities with research now progressing into the clinical trial phase.

Author Contributions: Conceptualization, J.H.F.; writing—original draft preparation, J.H.F., D.N.S., A.Y.P., S.S.K.; writing-review and editing, J.H.F., D.N.S., A.Y.P., S.S.K.

Funding: This research received no external funding.

Acknowledgments: Thanks to Amanda McKinnon for administrative support.

Conflicts of Interest: The authors are employees of Marinova Pty Ltd.

\section{References}

1. Fitton, J.H.; Stringer, D.N.; Karpiniec, S.S. Therapies from Fucoidan: An Update. Mar. Drugs 2015, 13, 5920-5946. [CrossRef] [PubMed]

2. Wang, Y.; Xing, M.; Cao, Q.; Ji, A.; Liang, H.; Song, S. Biological Activities of Fucoidan and the Factors Mediating Its Therapeutic Effects: A Review of Recent Studies. Mar. Drugs 2019, 17, 183. [CrossRef] [PubMed]

3. Van Weelden, G.; Bobinski, M.; Okla, K.; van Weelden, W.J.; Romano, A.; Pijnenborg, J.M.A. Fucoidan Structure and Activity in Relation to Anti-Cancer Mechanisms. Mar. Drugs 2019, 17, 32. [CrossRef] [PubMed]

4. Citkowska, A.; Szekalska, M.; Winnicka, K. Possibilities of Fucoidan Utilization in the Development of Pharmaceutical Dosage Forms. Mar. Drugs 2019, 17, 458. [CrossRef] [PubMed]

5. Wang, J.; Geng, L.; Yue, Y.; Zhang, Q. Use of fucoidan to treat renal diseases: A review of 15 years of clinic studies. Prog. Mol. Biol. Transl. Sci. 2019, 163, 95-111. [CrossRef] [PubMed]

6. Zheng, K.H.; Kaiser, Y.; Poel, E.; Verberne, H.; Aerts, J.; Rouzel, F.; Stroes, E.; Letourneur, D.; Chauvierre, C. 99Mtc-Fucoidan As Diagnostic Agent For P-Selectin Imaging: First-In-Human Evaluation (Phase I). Atherosclerosis 2019, 287, e143. [CrossRef] 
7. A.M.D. Inc. ARC Research Studies. Available online: https://www.arcmedicaldevices.com/presentations/ (accessed on 20 August 2019).

8. Charboneau, A.J.; Delaney, J.P.; Beilman, G. Fucoidans inhibit the formation of post-operative abdominal adhesions in a rat model. PLOS ONE 2018, 13, e0207797. [CrossRef]

9. Chua, E.G.; Verbrugghe, P.; Perkins, T.T.; Tay, C.Y. Fucoidans Disrupt Adherence of Helicobacter pylori to AGS Cells In Vitro. Evid. Complement. Altern. Med. eCAM 2015, 2015, 120981. [CrossRef]

10. Besednova, N.N.; Zaporozhets, T.S.; Somova, L.M.; Kuznetsova, T.A. Review: prospects for the use of extracts and polysaccharides from marine algae to prevent and treat the diseases caused by Helicobacter pylori. Helicobacter 2015, 20, 89-97. [CrossRef]

11. Lin, Y.H.; Lu, K.Y.; Tseng, C.L.; Wu, J.Y.; Chen, C.H.; Mi, F.L. Development of genipin-crosslinked fucoidan/chitosan-N-arginine nanogels for preventing Helicobacter infection. Nanomedicine 2017, 12, 1491-1510. [CrossRef]

12. Oka, S.; Okabe, M.; Tsubura, S.; Mikami, M.; Imai, A. Properties of fucoidans beneficial to oral healthcare. Odontology 2019. [CrossRef] [PubMed]

13. Park, J.; Cha, J.D.; Choi, K.M.; Lee, K.Y.; Han, K.M.; Jang, Y.S. Fucoidan inhibits LPS-induced inflammation in vitro and during the acute response in vivo. Int. Immunopharmacol. 2017, 43, 91-98. [CrossRef] [PubMed]

14. Hanisch, F.G.; Hansman, G.S.; Morozov, V.; Kunz, C.; Schroten, H. Avidity of alpha-fucose on human milk oligosaccharides and blood group-unrelated oligo/polyfucoses is essential for potent norovirus-binding targets. J. Biol. Chem. 2018, 293, 11955-11965. [CrossRef] [PubMed]

15. Sanjeewa, K.K.A.; Lee, J.S.; Kim, W.S.; Jeon, Y.J. The potential of brown-algae polysaccharides for the development of anticancer agents: An update on anticancer effects reported for fucoidan and laminaran. Carbohydr. Polym. 2017, 177, 451-459. [CrossRef]

16. Negishi, H.; Mori, M.; Mori, H.; Yamori, Y. Supplementation of elderly Japanese men and women with fucoidan from seaweed increases immune responses to seasonal influenza vaccination. J. Nutr. 2013, 143, 1794-1798. [CrossRef]

17. Dutot, M.; Grassin-Delyle, S.; Salvator, H.; Brollo, M.; Rat, P.; Fagon, R.; Naline, E.; Devillier, P. A marine-sourced fucoidan solution inhibits Toll-like-receptor-3-induced cytokine release by human bronchial epithelial cells. Int. J. Biol. Macromol. 2019, 130, 429-436. [CrossRef]

18. Klettner, A. Fucoidan as a Potential Therapeutic for Major Blinding Diseases-A Hypothesis. Mar. Drugs 2016, 14, 31. [CrossRef]

19. Dorschmann, P.; Bittkau, K.S.; Neupane, S.; Roider, J.; Alban, S.; Klettner, A. Effects of Fucoidans from Five Different Brown Algae on Oxidative Stress and VEGF Interference in Ocular Cells. Mar. Drugs 2019, 17, 258. [CrossRef]

20. Felisilda, B.M.B.; Alvarez de Eulate, E.; Stringer, D.N.; Fitton, J.H.; Arrigan, D.W.M. Electrochemical behaviour at a liquid-organogel microinterface array of fucoidan extracted from algae. Analyst 2017, 142, 3194-3202. [CrossRef]

21. Warttinger, U.; Giese, C.; Harenberg, J.; Holmer, E.; Krämer, R. A fluorescent probe assay (Heparin Red) for direct detection of heparins in human plasma. Anal. Bioanal. Chem. 2016, 408, 8241-8251. [CrossRef]

22. Espinosa-Velazquez, G.; Ramos-de-la-Pena, A.M.; Montanez, J.; Contreras-Esquivel, J.C. Rapid physicochemical characterization of innovative fucoidan/fructan powders by ATR-FTIR. Food Sci. Biotechnol. 2018, 27, 411-415. [CrossRef] [PubMed]

23. Zhu, Z.; Zhu, B.; Ai, C.; Lu, J.; Wu, S.; Liu, Y.; Wang, L.; Yang, J.; Song, S.; Liu, X. Development and application of a HPLC-MS/MS method for quantitation of fucosylated chondroitin sulfate and fucoidan in sea cucumbers. Carbohydr. Res. 2018, 466, 11-17. [CrossRef] [PubMed]

24. Fitton, J.H.; Stringer, D.N.; Karpiniec, S.S.; Park, A.Y. The manufacture, characterization, and uses of fucoidans from macroalgae. In Enzymatic Technologies for Marine Polysaccharides; CRC Press: Boca Raton, FL, USA, 2019; pp. 47-60.

25. Pozharitskaya, O.N.; Shikov, A.N.; Faustova, N.M.; Obluchinskaya, E.D.; Kosman, V.M.; Vuorela, H.; Makarov, V.G. Pharmacokinetic and Tissue Distribution of Fucoidan from Fucus vesiculosus after Oral Administration to Rats. Mar. Drugs 2018, 16, 132. [CrossRef] [PubMed]

26. Tokita, Y.; Hirayama, M.; Nakajima, K.; Tamaki, K.; Iha, M.; Nagamine, T. Detection of Fucoidan in Urine after Oral Intake of Traditional Japanese Seaweed, Okinawa mozuku (Cladosiphon okamuranus Tokida). J. Nutr. Sci. Vitaminol. 2017, 63, 419-421. [CrossRef] [PubMed] 
27. Tokita, Y.; Nakajima, K.; Mochida, H.; Iha, M.; Nagamine, T. Development of a fucoidan-specific antibody and measurement of fucoidan in serum and urine by sandwich ELISA. Biosci. Biotechnol. Biochem. 2010, 74, 350-357. [CrossRef]

28. Zhao, X.; Guo, F.; Hu, J.; Zhang, L.; Xue, C.; Zhang, Z.; Li, B. Antithrombotic activity of oral administered low molecular weight fucoidan from Laminaria Japonica. Thromb. Res. 2016, 144, 46-52. [CrossRef]

29. Zhang, E.; Chu, F.; Xu, L.; Liang, H.; Song, S.; Ji, A. Use of fluorescein isothiocyanate isomer I to study the mechanism of intestinal absorption of fucoidan sulfate in vivo and in vitro. Biopharm. Drug Dispos. 2018, 39, 298-307. [CrossRef]

30. Masterson, C.H.; Curley, G.F.; Laffey, J.G. Modulating the distribution and fate of exogenously delivered MSCs to enhance therapeutic potential: knowns and unknowns. Intensive Care Med. Exp. 2019, 7, 41. [CrossRef]

31. Lee, J.H.; Yun, C.W.; Hur, J.; Lee, S.H. Fucoidan Rescues p-Cresol-Induced Cellular Senescence in Mesenchymal Stem Cells via FAK-Akt-TWIST Axis. Mar. Drugs 2018, 16, 121. [CrossRef]

32. Kan, J.; Hood, M.; Burns, C.; Scholten, J.; Chuang, J.; Tian, F.; Pan, X.; Du, J.; Gui, M. A Novel Combination of Wheat Peptides and Fucoidan Attenuates Ethanol-Induced Gastric Mucosal Damage through Anti-Oxidant, Anti-Inflammatory, and Pro-Survival Mechanisms. Nutrients 2017, 9, 978. [CrossRef]

33. Kan, J.; Cheng, J.; Xu, L.; Hood, M.; Zhong, D.; Cheng, M.; Liu, Y.; Chen, L.; Du, J. The combination of wheat peptides and fucoidan protects against chronic superficial gastritis and alters gut microbiota: a double-blinded, placebo-controlled study. Eur. J. Nutr. 2019. [CrossRef] [PubMed]

34. Takahashi, H.; Kawaguchi, M.; Kitamura, K.; Narumiya, S.; Kawamura, M.; Tengan, I.; Nishimoto, S.; Hanamure, Y.; Majima, Y.; Tsubura, S.; et al. An Exploratory Study on the Anti-inflammatory Effects of Fucoidan in Relation to Quality of Life in Advanced Cancer Patients. Integr. Cancer Ther. 2018, 17, 282-291. [CrossRef] [PubMed]

35. Tocaciu, S.; Oliver, L.; Lowenthal, R.; Peterson, G.M.; Patel, R.; Shastri, M.; McGuinness, G.; Olesen, I.; Fitton, J.H. The effect of Undaria pinnatifida fucoidan on the pharmacokinetics of letrozole and tamoxifen in patients with breast cancer. Integr. Cancer Ther. 2016, 2016, 99-105. [CrossRef] [PubMed]

36. Sakai, C.; Abe, S.; Kouzuki, M.; Shimohiro, H.; Ota, Y.; Sakinada, H.; Takeuchi, T.; Okura, T.; Kasagi, T.; Hanaki, K. A Randomized Placebo-controlled Trial of an Oral Preparation of High Molecular Weight Fucoidan in Patients with Type 2 Diabetes with Evaluation of Taste Sensitivity. Yonago Acta Med. 2019, 62, 14-23. [CrossRef]

37. Wright, C.M.; Bezabhe, W.; Fitton, J.H.; Stringer, D.N.; Bereznicki, L.R.E.; Peterson, G.M. Effect of a Fucoidan Extract on Insulin Resistance and Cardiometabolic Markers in Obese, Nondiabetic Subjects: A Randomized, Controlled Trial. J. Altern. Complement. Med. 2019, 25, 346-352. [CrossRef]

38. Tsubura, S.S.A. Case report using $4 \%$ fucoidan cream for recurrent oral herpes labialis: Patient symptoms markedly improved in terms of time to healing and time to loss of discomfort. Dent. Open, J. 2017, 4, 19-23. [CrossRef]

39. Zayed, A.; Muffler, K.; Hahn, T.; Rupp, S.; Finkelmeier, D.; Burger-Kentischer, A.; Ulber, R. Physicochemical and Biological Characterization of Fucoidan from Fucus vesiculosus Purified by Dye Affinity Chromatography. Mar. Drugs 2016, 14, 79. [CrossRef]

40. Kadena, K.; Tomori, M.; Iha, M.; Nagamine, T. Absorption Study of Mozuku Fucoidan in Japanese Volunteers. Mar Drugs 2018, 16, 254. [CrossRef]

41. Study of Tolerance, Biodistribution and Dosimetry of Fucoidan Radiolabeled by Technetium-99m. Available online: https://ClinicalTrials.gov/show/NCT03422055 (accessed on 11 September 2019).

42. Li, R.; Boyd-Moss, M.; Long, B.; Martel, A.; Parnell, A.; Dennison, A.J.C.; Barrow, C.J.; Nisbet, D.R.; Williams, R.J. Facile control over the supramolecular ordering of self-assembled peptide scaffolds by simultaneous assembly with a polysacharride. Sci. Rep. 2017, 7, 4797. [CrossRef]

43. Maclean, F.L.; Wang, Y.; Walking, R.; Home, M.K.; Williams, R.J.; Nisbet, D.R. Reducing astrocytic scarring after traumatic brain injury with a multifaceted anti-inflammatory hydrogel system. ACS Biomater. Sci. Eng. 2017, 3, 2542-2549. [CrossRef]

44. Li, R.; Pavuluri, S.; Bruggeman, K.; Long, B.M.; Parnell, A.J.; Martel, A.; Parnell, S.R.; Pfeffer, F.M.; Dennison, A.J.C.; Nicholas, K.R.; et al. Coassembled nanostructured bioscaffold reduces the expression of proinflammatory cytokines to induce apoptosis in epithelial cancer cells. Nanomed. Nanotechnol. Biol. Med. 2016. [CrossRef] [PubMed] 
45. Benbow, N.L.; Webber, J.L.; Karpiniec, S.; Krasowska, M.; Ferri, J.K.; Beattie, D.A. The influence of polyanion molecular weight on polyelectrolyte multilayers at surfaces: protein adsorption and protein-polysaccharide complexation/stripping on natural polysaccharide films on solid supports. Phys. Chem. Chem. Phys. 2017, 19, 23790-23801. [CrossRef] [PubMed]

46. Wang, P.; Kankala, R.K.; Chen, B.; Long, R.; Cai, D.; Liu, Y.; Wang, S. Poly-allylamine hydrochloride and fucoidan-based self-assembled polyelectrolyte complex nanoparticles for cancer therapeutics. J. Biomed. Mater. Res. A 2019, 107, 339-347. [CrossRef] [PubMed]

47. Pawar, V.K.; Singh, Y.; Sharma, K.; Shrivastav, A.; Sharma, A.; Singh, A.; Meher, J.G.; Singh, P.; Raval, K.; Kumar, A.; et al. Improved chemotherapy against breast cancer through immunotherapeutic activity of fucoidan decorated electrostatically assembled nanoparticles bearing doxorubicin. Int. J. Biol. Macromol. 2019, 122, 1100-1114. [CrossRef]

48. Manivasagan, P.; Hoang, G.; Santha Moorthy, M.; Mondal, S.; Minh Doan, V.H.; Kim, H.; Vy Phan, T.T.; Nguyen, T.P.; Oh, J. Chitosan/fucoidan multilayer coating of gold nanorods as highly efficient near-infrared photothermal agents for cancer therapy. Carbohydr. Polym. 2019, 211, 360-369. [CrossRef]

49. Shin, S.W.; Jung, W.; Choi, C.; Kim, S.Y.; Son, A.; Kim, H.; Lee, N.; Park, H.C. Fucoidan-Manganese Dioxide Nanoparticles Potentiate Radiation Therapy by Co-Targeting Tumor Hypoxia and Angiogenesis. Mar. Drugs 2018, 16, 510. [CrossRef]

50. Pajovich, H.T.; Banerjee, I.A. Biomineralization of fucoidan-peptide blends and their potential applications in bone tissue regeneration. J. Funct. Biomater. 2017, 8, 41. [CrossRef]

51. Ozaltin, K.; Lehocky, M.; Humpolicek, P.; Pelkova, J.; Saha, P. A New Route of Fucoidan Immobilization on Low Density Polyethylene and Its Blood Compatibility and Anticoagulation Activity. Int. J. Mol. Sci. 2016, 17, 908. [CrossRef]

52. Jeong, Y.; Thuy, L.T.; Ki, S.H.; Ko, S.; Kim, S.; Cho, W.K.; Choi, J.S.; Kang, S.M. Multipurpose Antifouling Coating of Solid Surfaces with the Marine-Derived Polymer Fucoidan. Macromol. Biosci. 2018, 18, e1800137. [CrossRef]

53. Li, B.; Aid-Launais, R.; Labour, M.N.; Zenych, A.; Juenet, M.; Choqueux, C.; Ollivier, V.; Couture, O.; Letourneur, D.; Chauvierre, C. Functionalized polymer microbubbles as new molecular ultrasound contrast agent to target P-selectin in thrombus. Biomaterials 2019, 194, 139-150. [CrossRef]

54. Li, R.; McRae, N.L.; McCulloch, D.R.; Boyd-Moss, M.; Barrow, C.J.; Nisbet, D.R.; Stupka, N.; Williams, R.J. Large and Small Assembly: Combining Functional Macromolecules with Small Peptides to Control the Morphology of Skeletal Muscle Progenitor Cells. Biomacromolecules 2018, 19, 825-837. [CrossRef] [PubMed]

55. Lee, M.C.; Huang, Y.C. Soluble eggshell membrane protein-loaded chitosan/fucoidan nanoparticles for treatment of defective intestinal epithelial cells. Int. J. Biol. Macromol. 2019, 131, 949-958. [CrossRef] [PubMed]

56. Goonoo, N.; Bhaw-Luximon, A.; Jonas, U.; Jhurry, D.; Schönherr, H. Enhanced differentiation of human preosteoblasts on electrospun blend fiber mats of polydioxanone and anionic sulfated polysaccharides. ACS Biomater. Sci. Eng. 2017, 3, 3447-3458. [CrossRef] [PubMed]

57. Wang, B.; Adhikari, B.; Mathesh, M.; Yang, W.; Barrow, C.J. Anchovy oil microcapsule powders prepared using two-step complex coacervation between gelatin and sodium hexametaphosphate followed by spray drying. Powder Technol. 2018. [CrossRef]

58. Chiang, C.S.; Lin, Y.J.; Lee, R.; Lai, Y.H.; Cheng, H.W.; Hsieh, C.H.; Shyu, W.C.; Chen, S.Y. Combination of fucoidan-based magnetic nanoparticles and immunomodulators enhances tumour-localized immunotherapy. Nat. Nanotechnol. 2018, 13, 746-754. [CrossRef]

59. Lu, H.T.; Chang, W.T.; Tsai, M.L.; Chen, C.H.; Chen, W.Y.; Mi, F.L. Development of Injectable Fucoidan and Biological Macromolecules Hybrid Hydrogels for Intra-Articular Delivery of Platelet-Rich Plasma. Mar. Drugs 2019, 17, 236. [CrossRef]

60. Ozaltin, K.; Lehocky, M.; Humpolicek, P.; Pelkova, J.; Di Martino, A.; Karakurt, I.; Saha, P. Anticoagulant Polyethylene Terephthalate Surface by Plasma-Mediated Fucoidan Immobilization. Polymers 2019, 11, 750. [CrossRef]

61. Zheng, Y.; Wang, T.; Tu, X.; Huang, Y.; Zhang, H.; Tan, D.; Jiang, W.; Cai, S.; Zhao, P.; Song, R.; et al. Gut microbiome affects the response to anti-PD-1 immunotherapy in patients with hepatocellular carcinoma. J. Immuno Ther. Cancer 2019, 7, 193. [CrossRef] 
62. Pryor, R.; Martinez-Martinez, D.; Quintaneiro, L.; Cabreiro, F. The Role of the Microbiome in Drug Response. Ann. Rev. Pharmacol. Toxicol. 2020, 60. [CrossRef]

63. Mendez, R.; Kesh, K.; Arora, N.; Di Martino, L.; McAllister, F.; Merchant, N.; Banerjee, S.; Banerjee, S. Microbial dysbiosis and polyamine metabolism as predictive markers for early detection of pancreatic cancer. Carcinogenesis 2019. [CrossRef]

64. Tilg, H.; Zmora, N.; Adolph, T.E.; Elinav, E. The intestinal microbiota fuelling metabolic inflammation. Nat. Rev. Immunol. 2019. [CrossRef] [PubMed]

65. Iannone, L.F.; Preda, A.; Blottière, H.M.; Clarke, G.; Albani, D.; Belcastro, V.; Carotenuto, M.; Cattaneo, A.; Citraro, R.; Ferraris, C.; et al. Microbiota-gut brain axis involvement in neuropsychiatric disorders. Expert Rev. Neurother. 2019, 1-14. [CrossRef] [PubMed]

66. Shang, Q.; Shan, X.; Cai, C.; Hao, J.; Li, G.; Yu, G. Dietary fucoidan modulates the gut microbiota in mice by increasing the abundance of Lactobacillus and Ruminococcaceae. Food Funct. 2016, 7, 3224-3232. [CrossRef] [PubMed]

67. Teruya, K.; Kusumoto, Y.; Eto, H.; Nakamichi, N.; Shirahata, S. Selective Suppression of Cell Growth and Programmed Cell Death-Ligand 1 Expression in HT1080 Fibrosarcoma Cells by Low Molecular Weight Fucoidan Extract. Mar. Drugs 2019, 17, 421. [CrossRef] [PubMed]

68. Xue, M.; Ji, X.; Liang, H.; Liu, Y.; Wang, B.; Sun, L.; Li, W. The effect of fucoidan on intestinal flora and intestinal barrier function in rats with breast cancer. Food Funct. 2018, 9, 1214-1223. [CrossRef] [PubMed]

69. Jun, J.Y.; Jung, M.J.; Jeong, I.H.; Yamazaki, K.; Kawai, Y.; Kim, B.M. Antimicrobial and Antibiofilm Activities of Sulfated Polysaccharides from Marine Algae against Dental Plaque Bacteria. Mar. Drugs 2018, 16, 301. [CrossRef] [PubMed]

70. Kan, J.; Du, J. The Combination of Wheat Peptides and Fucoidan Protects Against Chronic Superficial Gastritis and Regulates Gut Microbiota: A Double-blinded, Placebo-controlled Study (P06-104-19). Curr. Dev. Nutr. 2019, 3. [CrossRef]

71. Kosono, S.; Kasai, A.; Komaba, S.; Matsubara, T.; Sato, T.; Takahashi, D.; Toshima, K. Novel hemagglutinin-binding sulfated oligofucosides and their effect on influenza virus infection. Chem. Commun. 2018, 54, 7467-7470. [CrossRef]

72. Wang, W.; Wu, J.; Zhang, X.; Hao, C.; Zhao, X.; Jiao, G.; Shan, X.; Tai, W.; Yu, G. Inhibition of Influenza A Virus Infection by Fucoidan Targeting Viral Neuraminidase and Cellular EGFR Pathway. Sci. Rep. 2017, 7, 40760. [CrossRef]

73. Huang, T.H.; Chiu, Y.H.; Chan, Y.L.; Chiu, Y.H.; Wang, H.; Huang, K.C.; Li, T.L.; Hsu, K.H.; Wu, C.J. Prophylactic Administration of Fucoidan Represses Cancer Metastasis by Inhibiting Vascular Endothelial Growth Factor (VEGF) and Matrix Metalloproteinases (MMPs) in Lewis Tumor-Bearing Mice. Mar. Drugs 2015, 13, 1882-1900. [CrossRef]

74. Bobinski, M.; Okla, K.; Bednarek, W.; Wawruszak, A.; Dmoszynska-Graniczka, M.; Garcia-Sanz, P.; Wertel, I.; Kotarski, J. The Effect of Fucoidan, a Potential New, Natural, Anti-Neoplastic Agent on Uterine Sarcomas and Carcinosarcoma Cell Lines: ENITEC Collaborative Study. Arch. Immunol. Ther. Exp. 2019, 67, 125-131. [CrossRef] [PubMed]

75. Lee, J.; Lee, S.; Synytsya, A.; Capek, P.; Lee, C.W.; Choi, J.W.; Cho, S.; Kim, W.J.; Park, Y.I. Low Molecular Weight Mannogalactofucans Derived from Undaria pinnatifida Induce Apoptotic Death of Human Prostate Cancer Cells In Vitro and In Vivo. Mar. Biotechnol. 2018, 20, 813-828. [CrossRef]

76. Blaszczak, W.; Lach, M.S.; Barczak, W.; Suchorska, W.M. Fucoidan Exerts Anticancer Effects Against Head and Neck Squamous Cell Carcinoma In Vitro. Molecules 2018, 23, 302. [CrossRef] [PubMed]

77. Mathew, L.B.M.; Gaikwad, A.; Nyshadham, P.; Nugent, E.K.; Gonzalez, A.; Smith, J.A. Preclinical Evaluation of Safety of Fucoidan Extracts From Undaria pinnatifida and Fucus vesiculosus for Use in Cancer Treatment. Integr. Cancer Ther. 2016, 1-13. [CrossRef]

78. Dithmer, M.; Kirsch, A.M.; Richert, E.; Fuchs, S.; Wang, F.; Schmidt, H.; Coupland, S.E.; Roider, J.; Klettner, A. Fucoidan Does Not Exert Anti-Tumorigenic Effects on Uveal Melanoma Cell Lines. Mar. Drugs 2017, 15, 193. [CrossRef] [PubMed]

79. Hsu, H.-Y.; Lin, T.-Y.; Hu, C.-H.; Shu, D.T.F.; Lu, M.-K. Fucoidan upregulates TLR4/CHOP-mediated caspase-3 and PARP activation to enhance cisplatin-induced cytotoxicity in human lung cancer cells. Cancer Lett. 2018, 432, 112-120. [CrossRef] [PubMed] 
80. Corban, M.; Ambrose, M.; Pagnon, J.; Stringer, D.; Karpiniec, S.; Park, A.; Eri, R.; Fitton, J.H.; Gueven, N. Pathway Analysis of Fucoidan Activity Using a Yeast Gene Deletion Library Screen. Mar. Drugs 2019, 17, 54. [CrossRef] [PubMed]

81. Malyarenko, O.S.; Zdobnova, E.V.; Silchenko, A.S.; Kusaykin, M.I.; Ermakova, S.P. Radiosensitizing effect of the fucoidan from brown alga Fucus evanescens and its derivative in human cancer cells. Carbohydr. Polym. 2019, 205, 465-471. [CrossRef] [PubMed]

82. Yu, H.H.; Chengchuan Ko, E.; Chang, C.L.; Yuan, K.S.; Wu, A.T.H.; Shan, Y.S.; Wu, S.Y. Fucoidan Inhibits Radiation-Induced Pneumonitis and Lung Fibrosis by Reducing Inflammatory Cytokine Expression in Lung Tissues. Mar. Drugs 2018, 16, 392. [CrossRef]

83. Irhimeh, M.R.; Fitton, J.H.; Lowenthal, R.M. Fucoidan ingestion increases the expression of CXCR4 on human CD34+ cells. Exp. Hematol. 2007, 35, 989-994. [CrossRef]

84. Anisimova, N.Y.; Ustyuzhanina, N.E.; Bilan, M.I.; Donenko, F.V.; Ushakova, N.A.; Usov, A.I.; Kiselevskiy, M.V.; Nifantiev, N.E. Influence of Modified Fucoidan and Related Sulfated Oligosaccharides on Hematopoiesis in Cyclophosphamide-Induced Mice. Mar. Drugs 2018, 16, 333. [CrossRef] [PubMed]

85. Burney, M.; Mathew, L.; Gaikwad, A.; Nugent, E.K.; Gonzalez, A.O.; Smith, J.A. Evaluation Fucoidan Extracts From Undaria pinnatifida and Fucus vesiculosus in Combination With Anticancer Drugs in Human Cancer Orthotopic Mouse Models. Integr. Cancer Ther. 2018, 17, 755-761. [CrossRef] [PubMed]

86. Bonnard, T.; Yang, G.; Petiet, A.; Ollivier, V.; Haddad, O.; Arnaud, D.; Louedec, L.; Bachelet-Violette, L.; Derkaoui, S.M.; Letourneur, D.; et al. Abdominal aortic aneurysms targeted by functionalized polysaccharide microparticles: A new tool for SPECT imaging. Theranostics 2014, 4, 592-603. [CrossRef] [PubMed]

87. Vigne, J.; Cognet, T.; Guedj, K.; Morvan, M.; Merceron, O.; Louedec, L.; Choqueux, C.; Nicoletti, A.; Escoubet, B.; Chaubet, F.; et al. Early Detection of Localized Immunity in Experimental Autoimmune Myocarditis Using [(99m)Tc]Fucoidan SPECT. Mol. Imaging Biol. 2019. [CrossRef]

88. Juenet, M.; Aid-Launais, R.; Li, B.; Berger, A.; Aerts, J.; Ollivier, V.; Nicoletti, A.; Letourneur, D.; Chauvierre, C. Thrombolytic therapy based on fucoidan-functionalized polymer nanoparticles targeting P-selectin. Biomaterials 2018, 156, 204-216. [CrossRef]

89. Choi, Y.; Min, S.K.; Usoltseva, R.; Silchenko, A.; Zvyagintseva, T.; Ermakova, S.; Kim, J.K. Thrombolytic fucoidans inhibit the tPA-PAI1 complex, indicating activation of plasma tissue-type plasminogen activator is a mechanism of fucoidan-mediated thrombolysis in a mouse thrombosis model. Thromb. Res. 2018, 161, 22-25. [CrossRef]

90. Abdollah, M.R.A.; Carter, T.J.; Jones, C.; Kalber, T.L.; Rajkumar, V.; Tolner, B.; Gruettner, C.; Zaw-Thin, M.; Baguna Torres, J.; Ellis, M.; et al. Fucoidan Prolongs the Circulation Time of Dextran-Coated Iron Oxide Nanoparticles. ACS Nano 2018. [CrossRef]

91. Lahrsen, E.; Schoenfeld, A.K.; Alban, S. Size-dependent pharmacological activities of differently degraded fucoidan fractions from Fucus vesiculosus. Carbohydr. Polym. 2018, 189, 162-168. [CrossRef]

92. Lahrsen, E.; Liewert, I.; Alban, S. Gradual degradation of fucoidan from Fucus vesiculosus and its effect on structure, antioxidant and antiproliferative activities. Carbohydr. Polym. 2018, 192, 208-216. [CrossRef]

93. Kim, H.; Ahn, J.H.; Song, M.; Kim, D.W.; Lee, T.K.; Lee, J.C.; Kim, Y.M.; Kim, J.D.; Cho, J.H.; Hwang, I.K.; et al. Pretreated fucoidan confers neuroprotection against transient global cerebral ischemic injury in the gerbil hippocampal CA1 area via reducing of glial cell activation and oxidative stress. Biomed. Pharmacother. 2019, 109, 1718-1727. [CrossRef]

94. Alghazwi, M.; Smid, S.; Karpiniec, S.; Zhang, W. Comparative study on neuroprotective activities of fucoidans from Fucus vesiculosus and Undaria pinnatifida. Int. J. Biol. Macromol. 2019, 122, 255-264. [CrossRef] [PubMed]

95. Liang, Z.; Liu, Z.; Sun, X.; Tao, M.; Xiao, X.; Yu, G.; Wang, X. The Effect of Fucoidan on Cellular Oxidative Stress and the CatD-Bax Signaling Axis in MN9D Cells Damaged by 1-Methyl-4-Phenypyridinium. Front. Aging Neurosci. 2018, 10, 429. [CrossRef] [PubMed]

96. Meenakshi, S.; Umayaparvathi, S.; Saravanan, R.; Manivasagam, T.; Balasubramanian, T. Neuroprotective effect of fucoidan from Turbinaria decurrens in MPTP intoxicated Parkinsonic mice. Int. J. Biol. Macromol. 2016, 86, 425-433. [CrossRef] [PubMed] 
97. Bell, J.S.; Spencer, J.I.; Yates, R.L.; Yee, S.A.; Jacobs, B.M.; DeLuca, G.C. Invited Review: From nose to gut - the role of the microbiome in neurological disease. Neuropathol. Appl. Neurobiol. 2019, 45, 195-215. [CrossRef]

98. Zhang, L.; Hao, J.; Zheng, Y.; Su, R.; Liao, Y.; Gong, X.; Liu, L.; Wang, X. Fucoidan Protects Dopaminergic Neurons by Enhancing the Mitochondrial Function in a Rotenone-induced Rat Model of Parkinson's Disease. Aging Dis. 2018, 9, 590-604. [CrossRef] 